\title{
Economic Effects of Tax Evasion on Jordanian Economy
}

\author{
Taha Barakat AL-Shawawreh ${ }^{1} \&$ Belal Yousef AL-Smirat ${ }^{1}$ \\ ${ }^{1}$ Karak College University, AL-Balqa Applied University, Karak, Jordan \\ Correspondence: Taha Barakat AL-Shawawreh, Karak College University, AL -Balqa Applied University, Karak, \\ Jordan. E-mail: dr.tahashawawreh@yahoo.com
}

Received: April 18, 2016

doi:10.5539/ijef.v8n7p344

\begin{abstract}
This study aims to clarify the economic effects of tax evasion especially on the Jordanian economy. The researchers has depended on the literature to highlight the negative effects of tax evasion on the economy of states. And by analyzing some statistics published by the Economic and Social council of Jordan, the results showed the tax evasion in Jordan forms a real problem because it amounted a high rate of revenue. Therefore the government should treat the evaders by more rigor.
\end{abstract}

Keywords: tax evasion, taxpayers, economic effects

\section{Introduction}

The tax is considered one of the financial policy of the state tools, also it considered as one of the most important tributaries of the public treasury to local revenues. The states always seek to achieve many goals by applying the tax system. These goals can be either financial or social goals, or economic goals. The financial goal is one of the significant goals of the tax system, where taxes increase revenues of state treasury from internal sources. While the social goals of tax could be seen as the social responsibility of the government as a big organization. This is because tax is working to present concentration of wealth in the hands of a limited number of members of the community, also it has a role in shaping the policy of birth control in countries, such as China and India, or in encouraging the birth control policy as in Scandinavian Countries. Moreover, tax contributes to reduction of housing crisis by exempting materials used in the housing sector (Fleurbaey et al., 2006). The economic goals of tax are as follows:

1) Encouraging specific productive activities through tax exemption in whole or in part, where this method is used to encourage industrial and tourism investment in many countries.

2) Reduction of Economic recession, where economic recession leads to lower purchases and accumulation of products, the role of the states in such cases is to increase purchasing power of individuals through lowering tax rates and increase tax exemptions.

3) Reduce the phenomenon of concentration of economic projects by taxing the merged projects.

4) Encourage investment and savings through the exemption the returns of treasury bonds from tax in order to encourage their purchase (Leigh, 2010). This study provides the evidence of the negative effects of tax evasion on the national economy.

\section{Problem Statement and Questions}

Based on the rules calling for the imposition of the tax, which were set by Adam Smith in the book "The Wealth Of Nations" in the late eighteenth century (Blundell, 2006). Tax evasion becomes the stumbling block preventing the collection of taxes and spending in accordance with the tax rules, led by the Justice and Equality rule. Therefore, the problem of this study takes the following statement.

Tax Evasion is an unethical common practice, which leads to prevent governments from the implementation of vital projects, besides harming the taxpayers for the benefits of evaders.

\section{This Problem Was Discussed according to the Following Questions}

1) What are the reasons for tax evasion?

2) How much is the size of tax evasion in Jordan? 
3) What are the most effective tools to reduce tax evasion?

\section{The Study Objectives}

This study aims to achieve the following objectives:

- Determining the volume of tax evasion in Jordan.

- Exploring the causes and the used tools in tax evasion.

- Identifying the economic effects of tax evasion.

\section{The Study Importance}

Income tax represents the contribution of individuals and firms in the development of the country in which they live and work in it to gain several benefits such as; income, peace and security, education, healthcare, and etc.

Where the tax system imposes the deduction of a reasonable percentage from the earned income by individuals and firms to fund the services mentioned above, where a large percent of the community members benefit from these services. The importance of this study stems from this logic which requires a shared contribution to activate such governmental services which will lose their effectiveness in the case of funding shortage represented by the tax evasion.

\section{Methodology}

The descriptive approach was used in conducting this study through reviewing the related literature to shed light on the economic effects of tax evasion. In the next stage, the researchers has analyzed the published statistics issued by the Jordanian economic and social council, for the years 2010-2015 to identify the tax evasion volume and its negative impacts on Jordanian economy.

\section{Literature Review}

There are a lot of studies and researches that address the tax theme from different aspects in the literature, but because the purpose of this study is to explore the economic effects of tax evasion, the researchers has chosen the following studies:

Study by Lin and Yang (2001). Under the title: "A Dynamic Portfolio Choice Model of Tax Evasion: Comparative Statics of Tax Rates and its Implication for Economic Growth."

This study aims to examine the effects of shifting from static model to dynamic model in tax evasion. The study was conducted through computation of the size of tax evasion according to the two models. The main results of the study showed that higher tax rates reduce tax evasion in the static model, while they encourage tax evasion in the dynamic model.

Study by Alm (2012). Under the title: "Measuring, Exploring, and Controlling tax Evasion: Lessons from Theory, Experiment, and Field Studies."

The study aimed to evaluate the public understanding about tax evasion since what was stated by Allingham and Agnar Sandmo, who were launched the modern analysis of tax evasion in 1972. The study was conducted on information on individual compliance for a random sample of 50000 individual from the "Taxpayer Compliance Measurement Program" in the U.S.A. the researcher focused on three questions and their answers to assess the understanding of tax evasion. First, how do we measure the extent of tax evasion? Second, how can we explain these patterns of behavior? Third, how can we use these insights to control evasion?. The main results showed that the people who are interested have learned many things in the last 40 years, but there are still many gaps in their understanding, such as; how much evasion really occurs on the national and local levels? Do higher tax rates encourage/discourage Compliance? What is the audit role in tax evasion? Then the researchers recommended to develop the tax theory because one theory may not fit all individuals at all times.

Study by Agnar Sandmo (2004). Under the title: "The Theory of Tax Evasion: A Retrospective View."

This study aimed to shed light on some themes in the theory of tax evasion through examining the related studies starting from Allingham and Sandom 1972. The analysis of comparative statistics, were placed in the study as a measure of tax evasion in the original model of individual behavior, where the tax evasion decision is similar to portfolio choice.

The results showed that tax evasion is not an over whelming problem, and the marginal tax rate should be governed by effective measures and equity concerns. Firms may also be from the evaders of income tax because it pertains to human behavior.

Study by Chen (2003). Under the title: "Tax Evasion in a model of endogenous growth." 
This study aimed to link tax evasion with the standard "AK" Growth model and the public capital In this model, the government optimizes the tax rates, while individuals optimize tax evasion. The study examined the effects of three government policies; tax rates, tax evasion, and economic growth. The results showed that the three policies have a quantitative effects on discouraging tax evasion, while their effects on economic growth are very limited.

\section{Theoretical Background}

Tax evasion can be defined as an denial of the individual tax due to be paid either by provision of inaccurate or deceptive financial statements for tax departments or any other means legal or illegal to get rid of tax payment (Munther, 2006). Other researchers have defined tax evasion (Mousa, 2010), pointed out that tax evasion is an attempt by the tax payer to get rid of tax payment partially or completely, without being reflected as a burden on others.

Tax evasion has negative effects on the economy Rami, (2014); Cobham (2005) has argued that tax avoidance and tax evasion affect negatively on development funding which may lead the country to borrowing and bearing a high cost. Other researchers, for example (Slemrod, 2007) pointed out that tax evasion produces a tax gap that means how much tax should be paid, but is not paid voluntarily in a timely way. From here one can summarize the effects of tax evasion on the economics of any state as follows:

Decline in government investment, and the lower the frequency of public spending due to lower volume of public revenues earned by the state from taxpayers. And this may lead to increase the rate of poverty and unemployment from the point of view of the current researcher.

Because of the tax gap that resulted from tax evasion, the current researcher believes that such action overwhelms abiding citizens.

Expanding of tax evasion leads to internal and external borrowing to cover the shortage in the public revenue, and this means that the state became under the pressure of interest payments (Gorodnichenko et al., 2007).

With tax evasion, the base of tax justice will not be achieved due to non-payment of tax by evaders.

The tax evasion effects the moral side because it means corruption and lack for honesty that may inherit successive generations.

In order to illustrate why some tax payers used to practice the tax evasion, the researcher believes that the reasons of this wrong practice may be the tax regulations or the high tax rates or the weakness of tax awareness. For Jordan, the main cases of tax evasion are the following (Economic and Social Council, 2014):

Complexity and non-stability of the tax law in Jordan in terms of many of modifications, which leads to misunderstanding to the tax law.

Complacency in the imposition of sanctions on evaders.

The lack for data base about the activities of many of taxpayers such as; doctors, engineers, and advocators and others.

The lack for qualified employees in tax departments such as auditors, accountants.

Weak control procedures.

Accordingly, Table 1 below shows the estimated volume of tax evasion in Jordan for the years 2010-2015.

Table 1. Tax evasion (million JD)

\begin{tabular}{ccccccc}
\hline & \multicolumn{3}{c}{ Actual } & \multicolumn{3}{c}{ Estimated } \\
\cline { 2 - 5 } & 2010 & 2011 & 2012 & 2013 & 2014 & 2015 \\
\hline Tax Revenue & 2544.9 & 2569.8 & 2594.9 & 2698.7 & 2806.7 & 2919.0 \\
Non-tax revenues & 1885.6 & 1715.4 & 1766.9 & 1819.9 & 1910.9 & 2006.4 \\
Social Security & 648.7 & 767.9 & 909.0 & 1076.0 & 1273.8 & 1507.8 \\
Total & 5074.2 & 5053.1 & 5277.8 & 5594.6 & 5991.3 & 6433.2 \\
Gross Domestic Product & 1876.2 & 2047.7 & 2196.6 & 2416.0 & 2600.0 & 2790.4 \\
The tax burden & $27.1 \%$ & $24.7 \%$ & $24 \%$ & $23.2 \%$ & $23 \%$ & $23.1 \%$ \\
The Size of informal economy as a percentage of GDP & $22.1 \%$ & $21.1 \%$ & $21.4 \%$ & $22.1 \%$ & $23.2 \%$ & $24.5 \%$ \\
The size of informal economy & 4646.4 & 4325.5 & 4694.4 & 5337.1 & 6019.8 & 6845.5 \\
Tax evasion volume & 1122.5 & 1067.4 & 1126.4 & 1235.9 & 1387.2 & 1578.2 \\
\hline
\end{tabular}

Source: Economic and Social Council, 2014. 
Tabular analysis for the figures above.

Percentage of tax revenue to total revenue.

Table 2. Actual figures

\begin{tabular}{crl}
\hline $2010:$ & 2544.9 & $\times 100=50.2 \%$ \\
\hline \multirow{2}{*}{$2011:$} & 5074.2 & \\
\hline & 5053.1 & $\times 100=50.8 \%$ \\
\hline
\end{tabular}

This means that tax revenue forms the greater proportion of revenue, so, it is very important for the government treasury.

Table 3. Estimated figures

\begin{tabular}{|c|c|c|}
\hline 2012: & $\begin{array}{l}2394.9 \\
5277.8\end{array}$ & $\times 100=45.4 \%$ \\
\hline 2013: & $\begin{array}{l}2698.7 \\
5594.6\end{array}$ & $\times 100=48.2 \%$ \\
\hline 2014: & $\begin{array}{l}2806.7 \\
5991.3 \\
\end{array}$ & $\times 100=46.8 \%$ \\
\hline 2015: & $\begin{array}{l}2919.0 \\
6433.2\end{array}$ & $\times 100=45.4 \%$ \\
\hline
\end{tabular}

The ratios above show that tax revenue still high, but not exceed half revenue as happened in the actual period.

For the tax evasion, the percentage of tax evasion to total revenue amounted to $22 \%$ and $21 \%$ for the years 2010 , 2011 respectively. While, for the estimated period these ratios, were $21 \% 22 \%, 23 \%$ and $25 \%$ for the years 2012-2015 respectively. And stability of these ratios may due to the absence of government sanctions to combat tax evasion.

\section{Results and Recommendations}

\subsection{Rsults}

The main results of this study are:

- Tax evasion is unethical practice whether by individuals or firms.

- Tax evasion has negative impact on the economy in terms of reducing the government investments and financing vital projects.

- Reducing government investments leads to increase of unemployment rates.

- Tax evasion may push the state to rely on borrowing internally and externally, which put the state under new obligations of interest.

\subsection{Recommendations}

- Tax law in Jordan should be stable to achieve good understanding by taxpayers.

- The government should impose serious sanctions on evaders.

- The tax department should pay more attention to the human capital in terms of qualifications and experience, and moral courage.

\section{References}

Alm, J. (2012). Measuring, explaining, and controlling tax evasion: Lessons from theory, experiments, and field studies. International Tax and Public Finance, 19(1), 54-77. http://dx.doi.org/10.1007/s10797-011-9171-2

Blundell, R. (2006). Earned income tax credit policies: Impact and optimality: The Adam Smith Lecture, 2005. Labour Economics, 13(4), 423-443. http://dx.doi.org/10.1016/j.labeco.2006.04.001

Chen, B. L. (2003). Tax evasion in a model of endogenous growth. Review of Economic Dynamics, 6(2), 
381-403. http://dx.doi.org/10.1016/S1094-2025(03)00002-4

Cobham, A. (2005). Tax Evasion, Tax Avoidance and Development Finance. Working Paper Number 129, QEH Working Paper Sevies.

Fleurbaey, M., \& Maniquet, F. (2006). Fair income tax. The Review of Economic Studies, 73(1), 55-83. http://dx.doi.org/10.1111/j.1467-937X.2006.00369.x

Gorodmchenko, Y. et al. (2007). Myth and Reality of Fiat Tex Reform: Micro Estimates of Tax Evasion Response and Welfare Effects in Russia. Discussion Paper No.3267, December 2007.

Leigh, A. (2010). Who benefits from the earned income tax credit? Incidence among recipients, coworkers and firms. The BE Journal of Economic Analysis \& Policy, 10(1). http://dx.doi.org/10.2202/1935-1682.1994

Lin, W. Z., \& Yang, C. C. (2001). A dynamic portfolio choice model of tax evasion: Comparative statics of tax rates and its implication for economic growth. Journal of Economic Dynamics and Control, 25(11), 1827-1840. http://dx.doi.org/10.1016/S0165-1889(99)00081-0

Mousa, M. M. (2010). Tax Evasion and Combat Mechanism.

Munther, R. A. (2006). The Concept of Tax. Definition and Forms. Damascus University, Faculty of Civil Engineering.

Rami, A. H. (2014). What are the Effects of Tax Evasion on the state, and what are the Means and Suggestions to Reduce Tax Evasion? Bayt.com.

Sandmo, A. (2005). The theory of tax evasion: A retrospective view. National Tax Journal, $643-663$. http://dx.doi.org/10.17310/ntj.2005.4.02

Slemrod, J. (2007). Cheating Ourselves: The Economics of Tax Evasion. Journal of Economic Perspectives, 21(1), 325-48. http://dx.doi.org/10.1257/jep.21.1.25

\section{Copyrights}

Copyright for this article is retained by the author(s), with first publication rights granted to the journal.

This is an open-access article distributed under the terms and conditions of the Creative Commons Attribution license (http://creativecommons.org/licenses/by/3.0/). 